Wittgenstein and Buddhism 


\section{WITTGENSTEIN \\ AND \\ BUDDHISM}

Ghris Gudmunsen

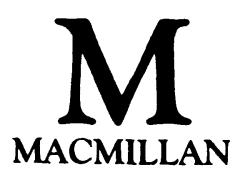


To Wendy, who thinks she was no help at all

\section{(C) Chris Gudmunsen 1977}

Softcover reprint of the hardcover 1st edition 1977

All rights reserved. No reproduction, copy or transmission of this publication may be made without written permission.

No paragraph of this publication may be reproduced, copied or transmitted save with written permission or in accordance with the provisions of the Copyright Act 1956 (as amended).

Any person who does any unauthorised act in relation to this publication may be liable to criminal prosecution and civil claims for damages.

First published 1977

Reprinted 1986

Published by

MACMILLAN EDUCATION LTD

Houndmills, Basingstoke, Hampshire RG21 2XS

and London

Companies and representatives

throughout the world

ISBN 978-1-349-03130-6

ISBN 978-1-349-03128-3 (eBook)

DOI 10.1007/978-1-349-03128-3 


\section{Contents}

Preface

Acknowledgements

vii

ix

PART ONE: RUSSELL AND THE ABHIDHARMISTS

I Logic

Particulars, Qualities and Dharmas 3

Relations

Evaluations

Summary

10

14

2 Experience and its Objects I5

Sense-data

Mental States $\quad 24$

Unconditioned Dharmas $\quad 26$

PART TWO: WITTGENSTEIN AND THE MAHĀYĀNA

3 Sensations and Language 33

The Basic Criticism 33

Words $\quad 37$

Inner Life $\quad 39$

Some Wider Comparisons $\quad 4 \mathrm{I}$

Understanding what Pain Is

Why not Kant? $\quad 50$

'Neither Exists nor Doesn't' 52

4 Yogācāra Contributions 57

Mädhyamika and Yogācāra

Universals 60

5 Others and Myself $\quad 67$

The Importance of People $\quad 67$

The Meaning of ' $I$ '

6 Two 'Mental Acts' 81

Volition 81

Knowledge $\quad 89$ 
7 Ethics and Religion $\quad 94$

Ethics 94

Religion 102

8 Disconnection and Connection II I

Buddhism, Schopenhauer and Wittgenstein II

Conclusions 113

Notes $\quad 116$

Abbreviations and Bibliography 121

$\begin{array}{ll}\text { Index } & 125\end{array}$ 


\section{Preface}

What one might expect at the beginning of a book of this kind is an expression of regret that Eastern and Western philosophy, not having grown up together, are still shy on meeting. Very well: it is regrettable. It is true that they often seem to have dishearteningly little in common, but that makes it all the more exciting on the odd occasion when it is realised that much the same thing has been going on quite independently on both sides of Istanbul. I suppose that it would be more exciting still if it could be established that Wittgenstein's later work was not independent of Buddhist philosophy. But I shall be arguing in the last chapter that such a view, even though not wildly stupid, cannot really be correct.

The similarities between Wittgenstein and Buddhism, then, are fortuitous. This raises a question about what exactly I am trying to do in the following chapters and what would and would not be a valid method of doing it. Edward Conze, for instance, in an article called 'Spurious Parallels to Buddhist Philosophy' says that spurious parallels

often originate from a wish to find affinities with philosophers recognized and admired by the exponents of current academic philosophy, and intend to make Buddhist thinkers interesting and respectable by current Western standards. Since this approach is not only objectively unsound, but has also failed in its purpose to interest Western philosophers in the philosophies of the East, the time has now come to abandon it. ${ }^{1}$

It seems to me, on the other hand, that this view expressed by Conze has become an orthodoxy in Buddhist studies and that the time has now come to abandon it or at least to move on from it a little. What I wish to do is precisely that which is condemned by Conze. I do wish to find affinities with a philosopher recognised and admired by some exponents of current academic philosophy, though that is not all. Various recent academic philosophers, not least Wittgenstein, have had a considerable impact upon Christian theology, and there is no reason why the same should not apply to the Buddhist equivalent of Christian theology. But which, it might be asked, am I trying to do? Am I saying that Wittgenstein and certain schools of Buddhist philosophy were saying much the same thing; or am I offering a new interpretation of 
those schools in accordance with Wittgensteinian ideas? The answer is that I am doing both. The reason why the second does not invalidate the first is because, as I shall be arguing, only a Wittgensteinian interpretation will suffice for certain central Buddhist concepts. In other words, Buddhist philosophy once took a markedly Wittgensteinian turn.

In that same article of Conze's, he suggests four aspects of philosophical doctrines which need to be borne in mind to avoid spurious parallels. There is the formulation of certain propositions, the motives and purposes of the author, the kinds of arguments they use and the context in which the statements are made. I have, I hope, dealt satisfactorily with the first three, but the last - 'a context which is determined by the philosopher's predecessors and contemporaries, and by his social, cultural and religious background'2 - simply cannot, of course, apply here. The two contexts in question could hardly be more different; that is partly what makes the whole thing so interesting.

Interesting to whom, though? In view of the prevailing East-West philosophical apartheid there will, presumably, be two fairly distinct groups of readers of this book. To those interested more in Wittgenstein than in Buddhism I have nothing philosophically startling to say (although perhaps some of Wittgenstein's ideas may have a slightly different flavour after being set alongside similar ideas differently expressed). Any interest for them will be aroused largely by the novelty of the historical coincidences. Readers of Wittgenstein do not normally suffer from déjà $v u$ because they have never seen any reason to regard Buddhist philosophy as relevant to their concerns, perhaps regarding it as too tainted by mysticism or devotionalism to be hard-headed and painstaking. I hope that this will be seen to be a false dichotomy in this case. Those whose interest lies in Buddhism rather than in Wittgenstein will be familiar with parallels, spurious and otherwise, which have been held to obtain between Buddhism and Western philosophy. But apart from offering yet more of these, I have tried to show that academic philosophy can help to clarify religious statements. The approach of a modern Western philosopher often means trouble for the Christian theologian, who is not infrequently left with the feeling that his beliefs have been somehow demeaned. Buddhists have, I think, less to fear. If this is so, it has probably something to do with the fact that Buddhism has, for moșt of its life, been much more overtly philosophical than has Christianity. At all events, the school of Mahãyāna Buddhism with which I shall be chiefly concerned - the Mădhyamika - has least of all to fear, since it represents philosophical Buddhism par excellence.

To those interested in both Buddhism and Wittgenstein, I assume that I need say nothing at all. 


\section{Acknowledgements}

The author and publishers wish to thank Basil Blackwell and Mott Ltd, Oxford, for kindly granting permission to use extracts from The Blue and Brown Books and Philosophical Investigations by Ludwig Wittgenstein. 